\title{
EFFECT OF ENVIRONMENTAL FACTORS ON THE INVENTORY AND POPULATION OF VARROA MITE, VARROA DESTRUCTOR IN HONEY BEE APIS MELLIFERA COLONIES IN DOKKI, Giza, EGYPT
}

\author{
M.A.I. Abdel Azeim ${ }^{(1)}$, M.M.I. El-Refaay ${ }^{(1)}$, A.A.A. Abdelaal ${ }^{(2)}$, H.A. Sharaf El-Din ${ }^{(2)}$ \\ (1) Plant Protection Research Institute, Agricultural Research Center, Dokki , Giza, Egypt \\ ${ }^{(2)}$ Economic Ent. Department, Faculty of Agriculture, Menoufia, University, Egypt
}

Received: Aug. 28, 2021

Accepted: Oct. 27, 2021

\begin{abstract}
Population dynamics of Varroa destructor, Anderson and Trueman were studied along the autumn season of 2018 to the summer season of 2019 in 20 Apis mellifera, shaded or unshaded colonies, located in Dokki (Giza). The number of bees, the amount of open and capped brood, daily natural mortality, level of infestation of adult bees, and level of infestation of the brood, was monitored. The obtained results showed that the infestation with Varroa mite was high in winter and autumn and was low in spring and summer on brood and on adult worker bees. Relative humidity and outdoor temperature leading to great danger to bee colonies in dearth period. So, early mite control is very important. Successive brood cycles allow the population growth of Varroa, while the absence of brood during the summer months has the opposite effect of reducing populations of Varroa.
\end{abstract}

Key words: Varroa destructor, Apis mellifera, temperature, relative humidity, shading.

\section{INTRODUCTION}

The pathogenic action induced by the parasite related to honey bee colony population dynamics. Africanized bees have a degree of tolerance to the mite (De Jong et al., 1984; Camazine, 1986; Moritz and Mautz, 1990; Message and Goncalves, 1995, Vandame 1996; Medina and Martin, 1999; Anderson, 2000). Different growth of the mite population were also observed between European races, sub-races, ecotypes intra-racial and colonies and between different geographical areas (Ruttner and Hanel, 1992; . Branco et al., 1999). So, different pathogens i.e. viruses and may fungi are probably transferred to bees by Varroa. Recently, six viruses could be transferred to Varroa-infested bees (Tentcheva et al., 2004).

Honey bees, Apis mellifera, colonies infected with many pathogens, parasites and pests which endangering their health and life (Rosenkranz et al., 2010), This mite which feeds on haemolymph of brood and adult bees causes colony disorder, weakness, decreasing brood and deforming immature and mature bees (Kotwal and Abrol, 2013).

The majority of pathogens and parasites affecting honey bees have an almost worldwide distribution (Ellis et al., 2005) Also, parasitizing by Varroa destroys the mechanical protective barriers of the integument and impairs the immune system of the bees (Glinski, 1991) Honey bee colonies commonly die from $V$. destructor infestation within a few years if we're not treated (Fries et al. 2006), The temperature relations within honey bee colonies are complex, as honey bees thermo regulate their colonies according to the season and the presence or absence of brood (Seeley and Heinrich, 1981). Varroa destructor preferentially reproduces on at 32.5 $33.4^{\circ} \mathrm{C}$ temperature as it is the temperature on which drone brood maintained (Le Conte et al., 1990). Various workers have tried to investigate 
the relationship of Varroa destructor population with abiotic factors in Apis mellifera colonies (Martin el al., 2012).

It is also known that the dynamics of mite populations respond to the climatic conditions and the dynamics of bee populations (Presnce the brood and the number of male brood cells (Garcia Fernandez et al., 1995).

The present work aimed to record the population dynamics of this important parasite during the year to observe the infestations and to contribute the mite control program.

The parasite population was monitored on adult bees, brood, and the naturally falling parasite for a comprehensive evaluation of the building-up trends during the year.

To study the population dynamics of Varroa destructor in $A$. mellifera intermission colonies, the development of the infestation levels of adult bees and brood of workers sealed, and the number of mites on the bottom board of the hive was studied in relation to population dynamics bee for a one year period. In addition, calculations of the number of the mite population were determined. The research was carried out in a fixed apiary under typical conditions of the Egypt beekeeping

\section{MATERIALS AND METHODS}

This study was conducted during the period from October 2018 to September 2019 in the experimental apiary of Bee Research Department, Plant Protection Research Institute in Dokki, Giza, Egypt. Ten colonies equal in strength from Italian and others from Carniolan were chosen for the experiments.

This work was conducted to study seasonal fluctuations of the parasitic mite, Varroa destructor infecting honeybees colonies .
1- Seasonal fluctuations of Varroa destructor infesting Carniolan and Italian honeybee colonies :

Percentages of varroa infestation, at the four seasons under study, for each colony in the examined races was determined as older brood (pupae with pigment eyes), in 50 drone and worker cells. While, the infestation percentages of adult workers was determined in $\mathbf{1 0 0}$ living workers, which was directly taken directly from the combs. The previous methods were based according to the technique of (De Jong et al., 1982). Examination was done for Carniolan and Italian races at $\mathbf{1 4}$ days intervals.

To determine the rate of infestation with varroa mite on the adult worker of an experimental colony, sample of about 100 workers was taken in a glass bottle filled with a soapy water mixture, the bottle was closed with its cover, shacked well and the bottle content was sieved, from the detergent solution using a wire screen (12 mesh/inch). These mites were counted and the percentage of infestation of adult bees were calculated, using the following formula:

$$
\text { Infestation }(\%)=\frac{\text { Total no. of recorded mites }}{\text { Total no . of examined workers }} \times
$$

Mean outdoor temperatures $\left({ }^{\circ} \mathrm{C}\right)$ and relative humidity (RH\%) in Cairo (from October 2018 to September 2019) were obtained from :

https://www.wunderground.com

2- Natural mortality of mites fallen on the hive bottom board:

A white paper card covered with vaseline was put on the bottom board under the brood chambers of each colony and observed at two days intervals for the presence of naturally dead mites which were counted and recorded. The data were calculated as a mean /14 days according to Ritter et al., 1989, and Milani, 1990. 
3- Varroa mite numbers in the infested sealed brood cells:

The mite numbers (adult \&immature stages) found naturally inside the infested sealed brood cells for each examined colony were counted and recorded, the older brood (pupae with pigment eyes) in drone and worker cells (50 individuals for each and three colonies for each treatment). The examination was done for all groups of bee races every 14 days intervals as mentioned by the techniques of (Marcangeli et al., 1992). (Each application represent by three colonies to obtain the total number of 12 experimental colonies).

On brood, an area of $5 \times 5 \mathrm{~cm}$ of sealed worker brood in the middle of a sealed worker comb in every tested colony was examined. Their cells were scratched and mature or immature Varroa females in each cell were recorded. Also the infestation in cells was estimated.

In each tested colony, 25 of sealed worker brood cells were opened using a sharp needle and the number of infested cells with varroa mite was counted and recorded. The percentage of infestation was calculated according to the following formula:

Infestation $(\%)=\frac{\text { No. of infested cells }}{\text { Total no. of examined cells }} \times 100$

\section{4- Varroa extraction and enumeration:}

One hundred adult worker bees were collected, if possible from combs with open brood, and dipped in water to which detergent (washing-up liquid) has been added. The bees were collected in a wire net and removed after shaking several times.

The Varroa mites were counted and the infestation percentages (I.P.) were calculated using the equation:
Infestation $(\%)=\frac{\text { No. of Varroa mites }}{\text { Total no . of examined bees }} \times 100$

\section{5- Statistical analysis:}

Data collected were statistically analyzed and the treatment means were compared at $5 \%$ probability levels by LSD test, also correlation coefficients were calculated according to the methods given by Snedecor and Cochran (1967).

\section{RESULTS AND DISCUSSION}

1- Effect of shading process in Italian and Carniolan hybrids of honey bee colonies on Varroa destructor numbers along four seasons:

\section{1-1 Natural mortality of mites:}

As for shaded colonies, the obtained results in Table (1) and illustrated in Figs. $(1,3,4,5)$ indicated that the natural mortality of mites at Carniolan colonies was higher than those of Italian ones. Moreover, the highest numbers of natural mortality of the mites were recorded at Autumn season $(42,52,33.23$ mite per colony ) for Carniolan and Italian colonies, while the least numbers were recorded at Spring season (12.85, 22.59 mite per colony ) for Carniolan and Italian colonies.

Regarding to that unshaded colonies results in Table (2) and illustrated in Fig. $(2,3,4,5)$ indicated that the highest numbers of natural mortality of the mites were recorded at Autumn season (42,52, 33.23 mite per colony ) for Carniolan and Italian colonies, while the least numbers were recorded at Spring season (12.85, 22.59 mite per colony ) for Carniolan and Italian colonies.

As for numbers of varroa mites per 100 pupa, results in Tables $(1,2)$ indicated that the highest numbers of mites were recorded at Autumn season on Carniolan bee under shaded or unshaded conditions giving $\mathbf{5 1 . 4 5}$ mites, while the least numbers were recorded at 
M.A.l. Abdel Azeim, et al.,

Spring season under unshaded Italian colonies at Spring season giving only 4.1 mite per 100 pupa, Also, the least numbers of varroa mites were found under shaded or unshaded conditions on Carniolan bees giving 12.61 and 13.55 mites per 100 pupa.

As for numbers of varroa mites per 100 bee worker, results in Tables (1, 2 ) indicated that the highest numbers of mites were recorded at Autumn season on Carniolan bee under shaded or unshaded conditions giving 15.3 and 22.44 mites ,while the least numbers were recorded at Spring season under unshaded Italian colonies at Spring season giving only 3.17 mite per 100 worker, Also, the least numbers of varroa mites were found under shaded or unshaded conditions on Carniolan bees giving 4.11 and 5.61 mites per 100 worker.

Table (1): Effect of shading process in Italian and Carniolan hybrids of honey bee colonies on Varroa destructor population along four seasons.

\begin{tabular}{|c|c|c|c|c|c|}
\hline \multirow{2}{*}{ Season } & \multicolumn{3}{|c|}{ Italian colonies } & \multirow{2}{*}{ RH \% } & \multirow{2}{*}{ Temp } \\
\cline { 2 - 4 } & $\begin{array}{c}\text { No. dead } \\
\text { mites/colony }\end{array}$ & $\begin{array}{c}\text { No. mites/100 } \\
\text { pupae }\end{array}$ & $\begin{array}{c}\text { No. mites/100 } \\
\text { worker }\end{array}$ & & \\
\hline Autumn 2018 & $33.23 \pm 13.87$ & $32.61 \pm 3.18$ & $13.22 \pm 4.96$ & 57.033 & 21.167 \\
\hline Winter 2019 & $26.85 \pm 6.08$ & $40.33 \pm 8.09$ & $9.77 \pm 3.09$ & 51.567 & 15.833 \\
\hline Spring 2019 & $22.59 \pm 5.86$ & $23.61 \pm 7.74$ & $5.44 \pm 1.08$ & 45.3 & 25.933 \\
\hline Summer 2019 & $29.56 \pm 11.29$ & $27.17 \pm 13.27$ & $11.45 \pm 6.14$ & 54.9 & 29.533 \\
\hline \multirow{3}{*}{ Season } & \multicolumn{3}{|c|}{ Carniolan colonies } & \multirow{2}{*}{ RH \% } & Temp \\
\cline { 2 - 4 } & $\begin{array}{c}\text { No. dead } \\
\text { mites/colony }\end{array}$ & $\begin{array}{c}\text { No. mites/100 } \\
\text { pupae }\end{array}$ & $\begin{array}{c}\text { No. mites/100 } \\
\text { worker }\end{array}$ & & \\
\hline Autumn 2018 & $42.52 \pm 3.40$ & $51.45 \pm 12.23$ & $15 \pm 3.04$ & 57.033 & 21.167 \\
\hline Winter 2019 & $21.48 \pm 10.18$ & $31.39 \pm 14.73$ & $8.22 \pm 5.20$ & 51.567 & 15.833 \\
\hline Spring 2019 & $12.85 \pm 3.94$ & $13.55 \pm 3.04$ & $4.11 \pm 1.27$ & 45.3 & 25.933 \\
\hline Summer 2019 & $30.59 \pm 11.84$ & $26.50 \pm 15.62$ & $10.11 \pm 4.51$ & 54.9 & 29.533 \\
\hline
\end{tabular}

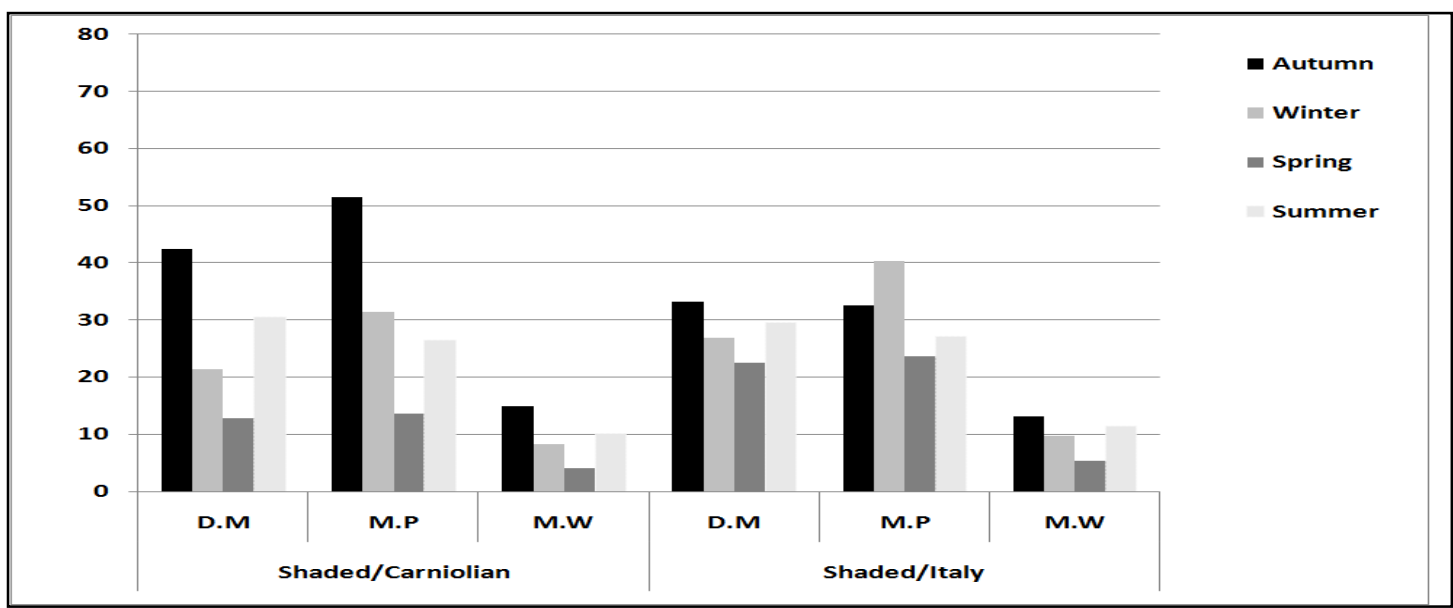

D. M. no dead mites/colony, M. P. no mites/100 pupae, M.W. no mites/100 worker

Fig (1): Effect of shading process in Italian and Carniolan hybrids of honey bee colonies on Varroa destructor population along four seasons. 
Table (2): Effect of unshaded Italian and Carniolan hybrids of honey bee colonies on Varroa destructor population along four seasons.

\begin{tabular}{|c|c|c|c|c|c|}
\hline \multirow{2}{*}{ Season } & \multicolumn{3}{|c|}{ Italian colonies } & \multirow{2}{*}{ RH \% } & \multirow{2}{*}{ Temp } \\
\cline { 2 - 4 } & $\begin{array}{c}\text { No. dead } \\
\text { mites/colony }\end{array}$ & $\begin{array}{c}\text { No. mites/100 } \\
\text { pupae }\end{array}$ & $\begin{array}{c}\text { No. mites/100 } \\
\text { worker }\end{array}$ & & \\
\hline Autumn 2018 & $18.56 \pm 3.17$ & $12.11 \pm 3.26$ & $5.72 \pm 2.34$ & 57.033 & 21.167 \\
\hline Winter 2019 & $12.22 \pm 3.04$ & $11.88 \pm 4.39$ & $5 \pm 0.44$ & 51.567 & 15.833 \\
\hline Spring 2019 & $8.85 \pm 1.87$ & $4 \pm 1.73$ & $3.17 \pm 0.73$ & 45.3 & 25.933 \\
\hline Summer 2019 & $12.33 \pm 4.37$ & $6.89 \pm 3.59$ & $4.39 \pm 0.98$ & 54.9 & 29.533 \\
\hline \multirow{3}{*}{ Season } & $\begin{array}{c}\text { No. dead } \\
\text { mites/colony }\end{array}$ & $\begin{array}{c}\text { No. mites/100 } \\
\text { pupae }\end{array}$ & $\begin{array}{c}\text { No. mites/100 } \\
\text { worker }\end{array}$ & RH \% & Temp \\
\cline { 2 - 4 } & $74.04 \pm 3.38$ & $51.45 \pm 12.19$ & $22.44 \pm 1.92$ & 57.033 & 21.167 \\
\hline Autumn 2018 & $46.18 \pm 23.63$ & $36.61 \pm 17.85$ & $12.89 \pm 4.56$ & 51.567 & 15.833 \\
\hline Winter 2019 & $25.74 \pm 4.50$ & $12.61 \pm 4.85$ & $5.61 \pm 1.46$ & 45.3 & 25.933 \\
\hline Spring 2019 & $25.67 \pm 22.17$ & $26.89 \pm 16.46$ & $13.33 \pm 7.59$ & 54.9 & 29.533 \\
\hline Summer2019 & $47.67 \pm 23$ & & &
\end{tabular}

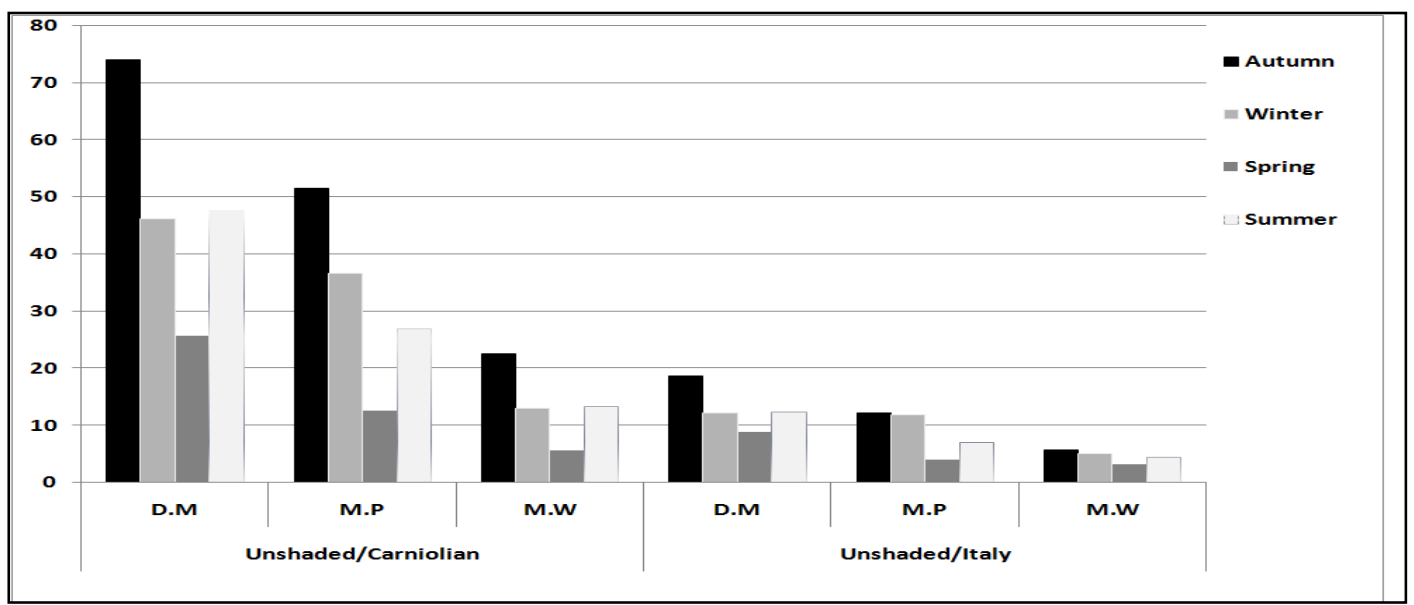

D. M. no dead mites/colony, M. P. no mites/100 pupae, M.W. no mites/100 worker

Fig (2): Effect of unshaded Italian and Carniolan hybrids of honey bee colonies on Varroa destructor numbers along four seasons.

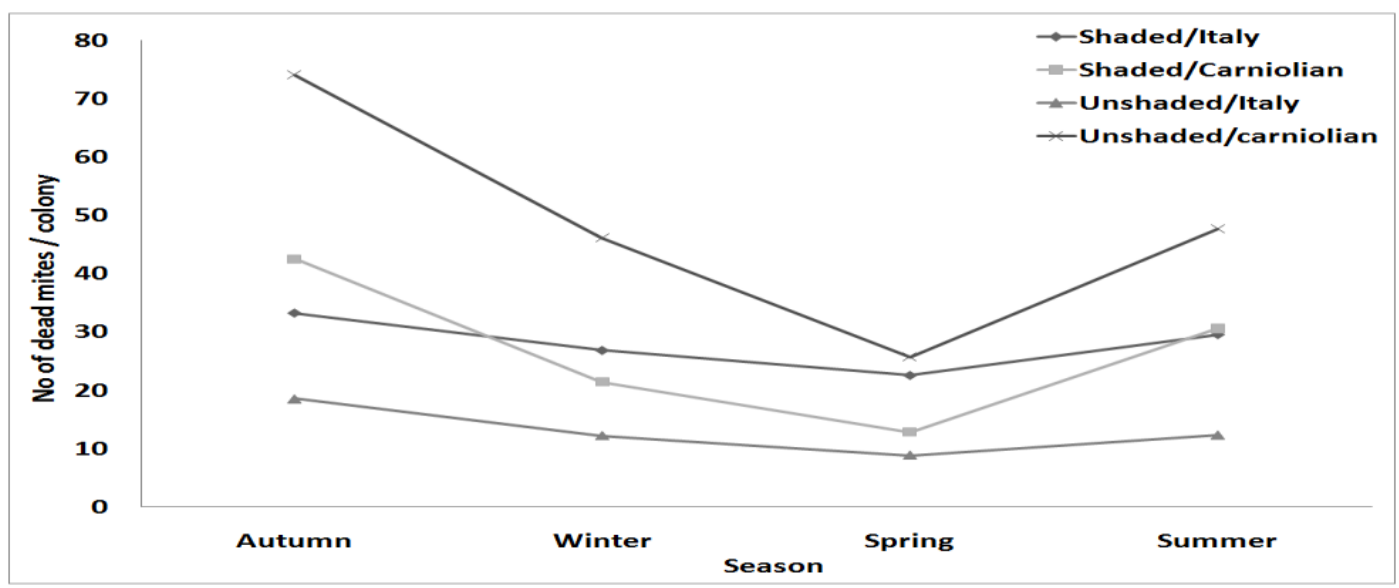

Fig (3): Seasonal mean numbers of dead mites /colony in the tested hybrids. 
M.A.I. Abdel Azeim, et al.,

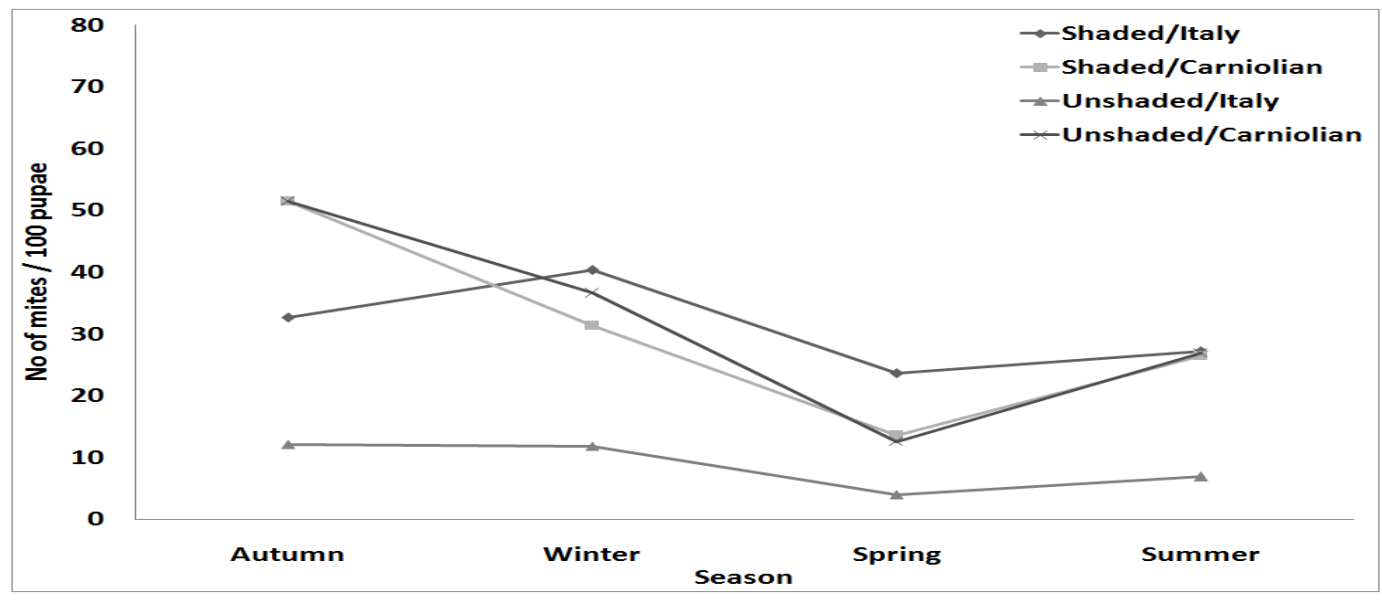

Fig (4): Seasonal mean number of mites /100 pupa in the tested hybrids.

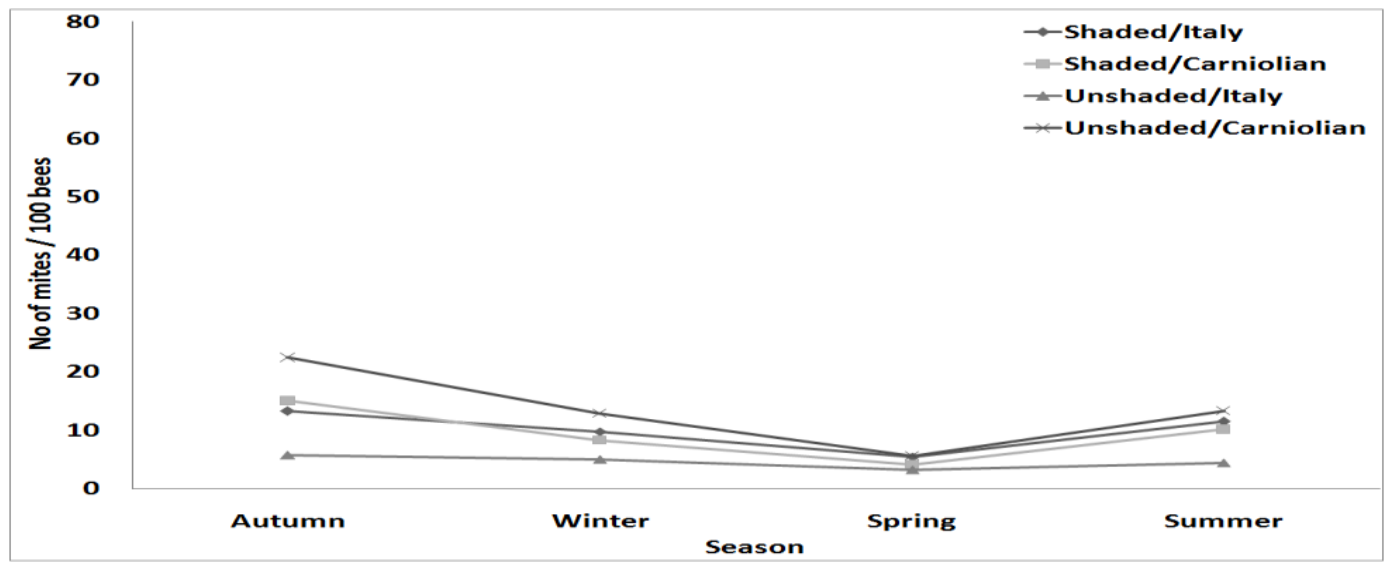

Fig (5): Seasonal means number of mites /100 worker bees in the tested hybrids.

2- Effect of air temperature and humidity on Varroa numbers infesting honey bee stages along 4 seasons under shading or unshaded process in Italian and Carniolan hybrids.

The statistical analysis of the obtained results in Tables $(1 \& 2)$ revealed that there were positive significant correlation between temperature degrees and varroa population as well as between relative humidity and varroa population as follow: 1- Temp. and No of mites / 100 worker for Italian hybrids in shaded colonies ( $r$ $=0.008372$ )

2-Temp. and No of mites / 100 worker for Carniolan hybrids in shaded colonies $(r=0.010263)$
3- Temp. and No of mites / 100 pupae for Italian hybrids in unshaded colonies $(r$ $=0.006872$ )

4- Temp. and No of dead mites / colony for Carniolan hybrids in unshaded colonies $(r=0.0500)$

5- $\mathrm{RH} \%$ and No of mites / 100 pupae for Italian hybrids in shaded colonies ( $r$ $=0.003061$ )

6- $\mathrm{RH} \%$ and No of mites / 100 pupae for Carniolan hybrids in shaded colonies ( $r=0.040889$ )

These data are in agreement with those of Helmy et al. (2005) who found that there was a highly positive correlation between dropped Varroa and each of mean temps. or \% R.H., since $r$ values were $0.714 \& 0.777$, respectively. 
Our investigation inspected the effect of $V$. destructor on slipping off and settlement size boundaries of Apis mellifera scutellata under common invasion levels. African bumble bees for the most part slip away because of trouble some natural conditions, human unsettling influence and parasitism (Hepburn and Radlof , 1998, Strauss et al., 2015). The stealing away pace of the analyzed Apis mellifera scutellata honey bees ( 7 out of 20 provinces, addressing $35 \%$ ) is like those revealed already in Ugandan honey bees (38-45\%) (Chemurot et al., 2016) and Ethiopian honey bees (41.1\%) (Gebremedhn et al., 2019). In this investigation, stealing away happened during July because of low measure of covered brood and diminished rummaging, particularly for dust, which had all the remarks of being influenced essentially by settlement size as opposed to levels of parasitism.

Comparable outcomes were accounted by Mcmenamin et al. (2017). States scrounged in a similar environmental territory, accordingly approached a comparable sort and measure of assets, so varieties in the measure of dust among provinces may be brought about by differences in searching effort by the grown-up honey bees and at last by their number. Brood infections, for example, American foulbrood, European foulbrood, Nosema and $V$. destructor can likewise prompt departing suddenly of bumble bee provinces (Kurze et al., 2016). As knowledgeable about different pieces of the world, bumble bee populaces in Africa have additionally been effected by the presentation of these microorganisms, parasites, and bugs just as territory misfortune (Hussein, 2001a, 2001b; Dietemann et al., 2009). In any case, the pace of stealing away estimated during the checking time frame in this investigation was not identified with $V$. destructor pervasion, yet to diminished quantities of covered brood. This is steady with past investigations which detailed that slipping away in Africanized bumble bees states happened following diminished brood, put away dust, nectar, and nectar (Winston et al., 1979).

Fries et al. (1994) revealed that before a province turns out to be seriously swarmed, $V$. destructor antagonistically meddles with brood creation. Along these lines, there is a requirement for close checking of $V$. destructor pervasion levels inside Apis mellifera scutellata states to decide the fine-scale elements of invasion, province size, and scrounging. Dust stockpiling levels have a direct effect on the province size as they are identified with quick state development rates through brood creation which thus may prompt expanded

One cause of this fall would be the drastic reduction of capped brood during the summer period. Robaux and Nolet (1985) point out that, in heavily infested colonies, capped brood decreased comparatively much faster than the open brood. They explain this drop that bees abandon the old and heavily infested brood firstly, and secondly the brood perished due to cooling caused by a reduction in the strength of the colony.

Moretto et al. (1991) found significant differences of infestation in three different climatic regions in Brazil, when they used the same races of bees. In addition, Otten (1991) recorded that the number of mites in brood cells were significantly different between colonies; the highest reproduction rate of mite in spring was in Apis mellifera carnica and in summer for Apis mellifera.

\section{REFERENCES}

Anderson, D.L. (2000). Variation in the parasitic bee mite, Varroa jacobsoni Oud. Apidologie 31:281-292

Branco, M.R., Kidd, N.A.C. and Pickard, R.S. (1999). Development of Varroa jacobsoni in colonies of Apis mellifera iberica and Mediterranean climate. Apidologie 30: 491-503.

Camazine, S. (1986). Differential Reproduction of the mite Varroa 
jacobsoni (Mesostigmata:Varroidae) on Africanized and European Honey bees (Hymenoptera: Apidae). Ann. Entomol. Soc. Am., 79: 801-803.

Chemurot M, Akol A. M., Masembe C. (2016) Factors influencing the prevalence and infestation levels of Varroa destructor in honeybee colonies in two highland agroecological zones of Uganda. Exp. Appl. Acarol., 68:497-508.

De Jong, D., De Andrea, D.R. and Concalves, L.S. (1982). A comparative analysis of shaking solutions for the detection of Varroa jacobsoni on adult honey bee. Apidologie 13: 297306.

De Jong, D., L.S. Concalves and R.A. Morse (1984). Dependence on climate of the virulence of Varroa jacobsoni. Bee Word 65: 117-121.

Dietemann, V., C.W.W. Pirk and R.M. Crewe (2009). Is there a need for conservation of honeybees in Africa. Apidologie 40: 285-295

Ellis, J.D. and P.A. Munn (2005). The worldwide health status of honey bees. Bee World, 86: 88-101.

Fries, I., S. Camazine and J. Sneyd (1994). Population dynamics of Varroa Jacobsoni: a model and a review. Bee World 75: 5-28.

Fries, I., A. Imdorf and P. Rosenkranz (2006). Survival of mite infested (Varroa destructor) honey bee (Apis mellifera) colonies in a Nordic climate, Apidologie, 37: 564-570.

Garcia-Fernandez, P., B.R. Rodriguez and F.J. Orantes - Bermejo (1995). Influence du climat sur le développement de la population de Varroa jacobsoni Oud dans des colonies d' Apis mellifeca iberica (Goetze) dans le sud de l'Espagne. Apidologie 26: 371-380.

Gebremedhn, H., B. Amssalu and L.D. Smet (2019). Factors restraining the population growth of Varroa destructor in Ethiopian honey bees
(Apis mellifera simensis). PLoS ONE 14: e0223236

Glinski, Z. (1991). The effect of Varroa jacobsoni on the incidence and course of chalkbrood disease in Apis mellifera $L$. colonies. Rev. Agric. Entom., 079- 09747.

Hepburn, H.R. and S.E. Radlof (1998). Honeybees of Africa. Springer, Berlin.

Helmy, A. Ghoniemy, Abdel-Halim M. Ismail and Ayman A. Owayss (2005). Relationship between Varroa Mite and Chalkbrood Fungus Infestations in Honeybees during Variable Ecological Conditions and Colony Performance The 4 international conference of Arab Beekeepers Union, Sahara Tourist Resort, Damascus, Syria, 24-27 Nov.

Hussein, M.H. (2001a). Beekeeping in Africa. Apiacta 1:23-48.

Hussein, M.H. (2001b). Beekeeping in Africa: II-Central, southern African countries and islands. In: Proc. 37th Int. Apic. Congress Durban, South Africa.

Kotwal, S. and Abrol, D. P. (2013). Evaluation of essential oils and cultural practices for the management of Varroa destructor. The bioscan 8(1): 15-20.

Kurze, C., J. Routtu and R.F.A. Moritz (2016). Parasite resistance and tolerance in honeybees at the individual and social level. Zoology, 119:290-297.

Le Conte, Y., G. Arnald, J. Trouiller and C. Masson (1990). Identification of brood pheromone in honeybees. Naturwissenschaften 77: 334-336.

Marcangeli, J.A., M.J. Eguaras and N.A. Fernandez (1992). Reproduction de Varroa jacobsoni sous les climats temperes d' Argentine. Apidologie (France). 23(1): 57-60."

Martin, S. J., A. C. Highfield, L. Brettell, E. M. Villalobos, G. C. Budge, M. Powell, S. Nikaido and D. C. Schroeded (2012). Global honey bee viral landscape 
altered by a parasitic mite. Science, 336: 1304-1306.

Mcmenamin, A., F. Mumoki and M. Frazier (2017). The impact of hive type on the behavior and health of honeybee colonies (Apis mellifera) in Kenya. Apidologie.

https://doi.org/10.1007/s13592-0170515-5

Medina medina, L. and S.J. Martin (1999). A comparative study of Varroa jacobsoni reproduction in worker cells of honey bees (Apis mellifera) in England and Africanized bees in Yucatan, Mexico. Exp. Appl. Acarol., 23: 659-667.

Message, D. and L.S. Concalves (1995). Effect of the size of worker brood cells of Africanized honey bee on infestation and reproduction of the ectoparasitic mite Varroa jacobsoni Oud. Apidologie 26: 381386.

Milani, N. (1990). Natural mortality of Varroa jacobsoni and infestation levels in bee hives. Apicoltura, 6:1-9.

Moretto, G., L.S. Goncaleves, D.E. Jong and M.Z. Bichetta (1991). The effect of infestations climate and bee race on Varroa jacobsoni in Brazil. Apidologi:, 22:197- 203.

Mortiz, R.F. and D. Mautz (1990). Development of Varroa jacobsoni of Apis mellifera capensis and Apis mellifera carnica. Apidologie 21: 5358.

Otten, C. (1991). Reproduction and population dynamic of Varroa jacobsoni In colonies of Apis mellifera $L$. of different origin. In Proceedings of the International Symposium on Recent Research on Bee Pathology, September 5-7,1990, Apimondia Publishing House, Germany, pp-67-69.

Robaux, P. and P. Nolet (1985). Nouvelles données sur le développement de Varroa jacobsoni au sein d'une colonie. Bull. Tech. Apic 12 : 9-20.
Rosenkranz, P., P. Aumeier and B. Ziegelmann (2010). Biology and control of Varroa destructor. Journal of Invertebrate Pathology, 103: 96-119.

Ritter, W., P. Michel, A. Schwendmann and M. Bartoldi (1989). Development of Varroa jacobsoni infestation in honey bee colonies in Tunisia. Biene.125 (10): 562-564.

Ruttner, F. and H. Hanel (1992). Active defense against Varroa mites in a Carniolan strain of honeybee (Apis melifera carnica Pollmann). Apidologie 23: 173 - 187.

Seeley, T. and B. Heinrich (1981). Regulation of temperature in the nests of social insects. pages 159-234 in B. Heinrich, ed. Insect thermoregulation. Wiley, New York.

Snedecor, G. W. and W. G. Cochran (1967). Statistical methods. The lowa State Univ. Press. Am es, lowa, USA. 6th ed.

Strauss, U., C.W.W. Pirk and R.M. Crewe (2015). Impact of Varroa destructor on honey bee (Apis mellifera) colony development in South Africa. Exp. Appl. Acarol., 65: 89-106.

Tentcheva, D., L. Gauthier, N. Zappulla and B. Dainat (2004). Prevalence and Seasonal Variations of Six Bee Viruses in Apis mellifera L. and Varroa destructor Mite Populations in France. Applied And Environmental Microbiology, p. 7185-7191.

Vandame, R. (1996). Importance de I'hybridation de l'hôte dans la tolérance à un parasite. Cas de l'acarien Varroa jacobsoni chez les races d'abeilles Apis mellifera européenne et africanisées, en climat tropical humide du Mexique. Ph.D dissertation, Université Claude Bernard, Lyon 1, France, 111 pp.

Winston, M.L., G.W. Otis and O.R. Taylor (1979). Absconding behaviour of the Africanized honeybee in South America. J. Apic. Res., 18:85-94. 
تاثير العوامل البيئية على حصر وتعداد اكاروس الفاروا فى طوائف نحل العسل فى منطقه الاقى فئ

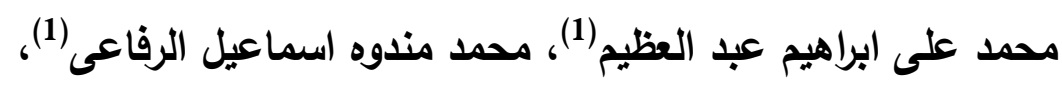

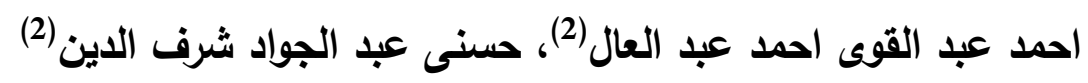

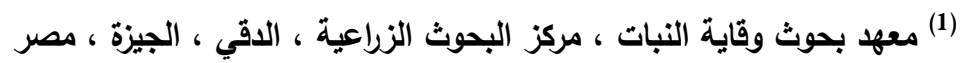

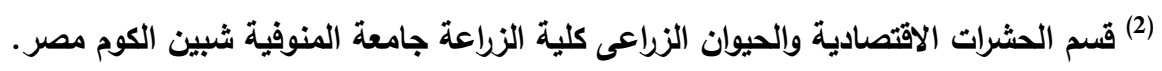

الملذص العربى

تمت دراسة ديناميكيه تعاد طفيل الفاروا لددة عامين (خريف 2018-صيف 2019) في 12 طائفه لنحل العسل

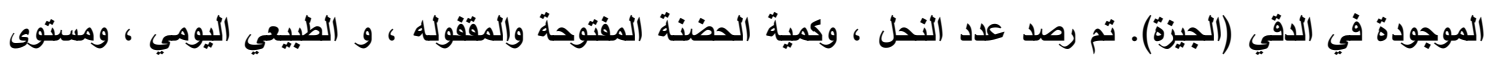

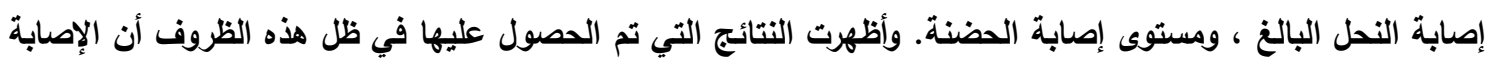

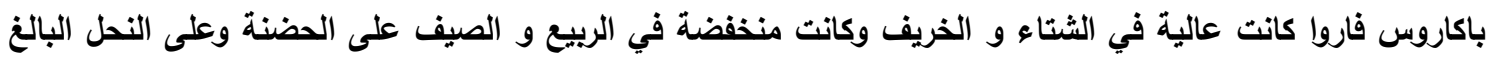

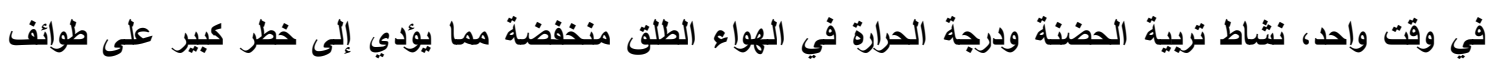

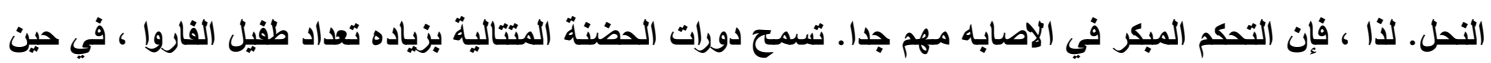

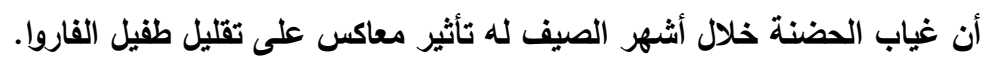

أسماء السادة المحكمين

أ.د/ عماد عز اللين أحمد ثروت معهل وقاية النبات - مركز بحوث النحل

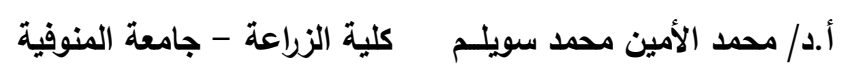

